\title{
A linguagem penal do contrato social brasileiro: o inimigo, a guerra e a construção da ordem contra a sociedade no Brasil (1822-1890)
}

\author{
Tiago Ivo Odon \\ Orientador: Prof. Dr. Eurico A. G. Cursino dos Santos \\ Curso: Doutorado em Sociologia \\ Data da Defesa: 12.04.2013
}

$\mathrm{O}$ objetivo do trabalho é propor uma interpretação histórico-social para a construção da ordem no Brasil após a sua independência, analisando como o sistema jurídico estatal foi estruturado e que ideias e interesses estavam em jogo nesse processo. Foram analisados textos de leis, discursos e pareceres de parlamentares e conselheiros de Estado, comentários de juristas, textos da imprensa, obras escritas e anotações de viajantes estrangeiros da época do Império. A pesquisa revelou que: 1) o sistema jurídico estatal brasileiro foi estruturado a partir da eleição de um inimigo da ordem pública e do papel central desempenhado pelo direito penal; 2) a classe dominante construiu um sistema jurídico repressivo, com o fim de manter a coesão social e impedir a iminente guerra civil, dada a heterogeneidade das ideias de valor cultivadas pelas diferentes classes sociais e o déficit de acordo moral sobre os interesses gerais e subjacentes na sociedade; 3 ) o ordenamento jurídico foi moldado principalmente para marcar e normalizar o escravo liberto e o pobre ocioso, camadas sociais consideradas perigosas no plano político-social e supérfluas no plano econômico, lançando mão de uma técnica de poder de controle da presença social e da circulação dessas pessoas; 4) o direito penal foi usado para intermediar os conflitos sociais, servir como "lei geral do Império" para questões da vida civil, inserir a mão-de-obra escrava no mercado livre e impor ao pobre livre uma subjetividade social voltada para o trabalho, tutelar práticas honestas de comércio e garantir a prestação de serviços para a agricultura. De tudo, podese extrair a conclusão geral de que a ideação social em torno do escravo e do pobre livre, os quais se transformaram num grande grupo social uniforme para a classe dominante, e o medo constante de uma guerra civil, levaram ao estabelecimento de um discurso da desigualdade essencial, paralelamente ao da hierarquia, o qual levou à criação de um aparato burocrático racional-legal voltado para a repressão, que tinha na linguagem da pena o único diálogo possível entre o Estado e a sociedade, e que persiste até os dias de hoje no imaginário social, como evidencia o peso e riqueza da legislação penal em vigor no Brasil.

Palavras-chave: Direito Penal, Contrato Social, Inimigo, Guerra Civil, Escravo. 